\title{
A Novel Micromixer with Three-Dimensionally Cross-Linked Capillary Array Structure Fabricated by Deep X-ray Lithography
}

\author{
Saki Kondo Non-member (Laboratory of advanced Science and Technology for Industry, University of Hyogo) \\ Yoshiaki Ukita Student Member (Laboratory of advanced Science and Technology for Industry, University of Hyogo, \\ Research Fellow (DC), Japan Society for the Promotion of Science) \\ Kuniyo Fujiwara Non-member (Laboratory of advanced Science and Technology for Industry, University of Hyogo) \\ Yuchi Utsumi Member (Laboratory of advanced Science and Technology for Industry, University of Hyogo)
}

Keywords : micromixing, three-dimension

There have been proposed many kinds of micromixers. Especially micromixer using three-dimensional (3D) structure is promising strategy for microfluidics. However there are some restrictions, for example it needs complex fabrication process with multiple photomasks, alignment and bonding. Furthermore it fabricated on planar substrate with long capillary, which is not favorable for large-scale integration aiming high-throughput screening because it needs large area to construct, while simultaneous operation of multiple microreactors for the high throughput screening is one of the biggest applications of microfluidics. We present novel micromixer using 3D microstructure with no complex fabrication process and long capillaries by using vertical fluid flow operation concept.

The new concept of this paper is to cross capillaries by controlling overlap level of crossing capillaries. The computational fluid dynamics (CFD) using CFD package 'FLUENT' is carried out to estimate the performance of the micromixer. To trace the mixing behavior, chemical species is assumed in initial condition. Figure 1 shows initial condition of water with chemical species (the property is the same as water) and mixed waters through cross-linked capillaries, and fig. 3 shows the time shift of the standard deviations (SD) of mass fraction of chemical species in the mixture. We assumed two crossing patterns which totally overlapping (fig. 1) and half overlapping (fig. 1) patterns and capillaries without crossing for

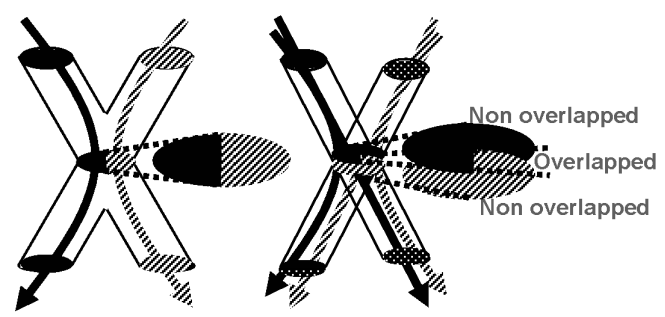

Fig. 1. Fluid behavior cross type filter
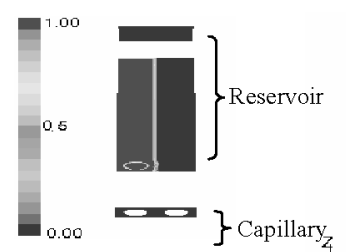

(a) Initial condition

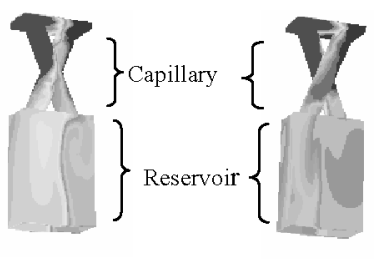

(b) Full cross-linked (After transmission) (c) Half cross-linked

Fig. 2. Analysis model of cross type filter control. The results indicate that the crossing structure has much better mixing performance and half overlapped structure provides the best mixing, because it induces branch of flows around the cross (fig. 1) while totally overlapped one does not exhibit such behavior because it maintains the stable laminar flow (fig. 1).

Typical micromachining is not suitable to control the level of overlap, because it needs very complex processes. To generate the cross-linked structure, deep x-ray lithography is applied. The PMMA resist attached with $\mathrm{x}$-ray masks are tilted up to $\mathrm{x}$-ray beam for first exposure and then tilted down for second exposed. The level of overlap is controlled by slightly rotating the masks around normal axis.

To evaluate the mixing performance of this micromixer we applied this micromixer to enzyme reaction. Enzyme and substrate are mixed by passing the micromixer and the product of the enzyme reaction is measured by spectroscopy. Figure 4 compares the mixing results with cross-linked capillaries and without cross-linked capillaries. The result shows that the mixing with cross-linked capillary structure is speeding up the enzyme reaction by obtaining the uniform mixture.

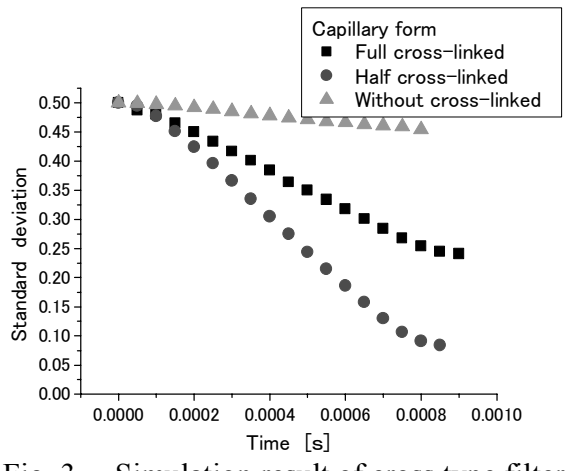

Fig. 3. Simulation result of cross type filter

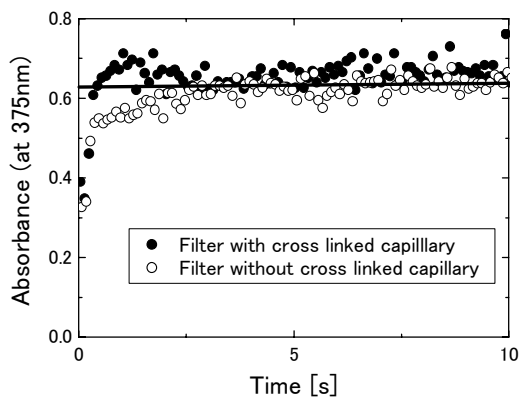

Fig. 4. Time shift of the enzyme reaction 


\section{$\mathrm{X}$ 線リソグラフィーにより作製した三次元交差型流路を持つ 新規マイクロミキサー}

$\begin{array}{llll}\text { 非会員 近藤 } & \text { 沙妃* } & \text { 学生員 浮田 芳昭 } \\ \text { 非会員 } & \text { 藤原 } & \text { 邦代* } \\ & \text { 正 員 内海 裕一* }\end{array}$

\section{A Novel Micromixer with Three-Dimensionally Cross-Linked Capillary Array Structure Fabricated by Deep X-ray Lithography}

Saki Kondo*, Non-member, Yoshiaki Ukita*,**, Student Member, Kuniyo Fujiwara*, Non-member, Yuichi Utsumi*, Member

A novel micromixer is proposed, fabricated and verified. The new concept of the micromixere is to cross-link the many capillaries in three-dimensional structure. The characteristic flow behaviors are simulated by using computational fluid dynamics(CFD) software "FLUENT". The results of the CFD shows unique mixing behavior in three-dimensionally cross-linked capillaries. The mixing performance of the micromixer is strongly influenced by controlling the three-dimensional crossing condition. The micromixer is fabricated by means of deep X-ray lithography with multi step exposure. The cross-linked capillary structures are successfully fabricated with controlled cross-link conditions. The performance of micromixer is evaluated by using a kind of enzyme reaction. By comparing mixture, mixed with cross-linked fluid filter and fluid filter without cross-linked capillaries, we found out the speeding up of the reaction by using new micromixer.

キーワード : マイクロミキシング, 三次元

Keywords : micromixing, three-dimension

\section{1. はじめに}

近年，環境，食品，医療など様々な分野において，高感 度，ハイスループット，そして，高効率な分析システムが 必要とされている。そこで, 注目されているのが $\mu$-TAS (Micro Total Analysis Systems) である。 $\mu$-TAS とは, 従来の 分析システムをマイクロ化したマイクロ流体デバイスを用 いて, 分析に必要な単位操作をマイクロチップ上で行なう システムである。システムを小型化することにより, 省資 源, 省エネルギー, 省スペース等を実現可能である。また, 分子拡散距離の短縮による反応速度の高速化が可能とな る。また, システムが小型化されたことにより, 精密な温 度制御や局所的な温度制御が可能となる。この様に, マイ クロシステムを用いることにより高効率な反応を実現でき る。しかし，マイクロ流体デバイスにはいくつか問題があ

* 兵庫県立大学 高度産業科学技術研究所

干678-1205 兵庫県赤穂郡上郡町光都 3-1-2

Laboratory of Advanced Science and Technology for Industry, University of Hyogo, 3-2-1, Kouto, Kamigori, Ako, Hyogo 678-1205

** 日本学術振興会

干102-8472 東京都千代田区一番町 8 番地

Japan Society for the Promotion of Science

8 Ichibancho Chiyodaku, Tokyo 102-8472
る。マイクロ流体デバイスはキャピラリーが平面空間に展 開するため, 単位操作に毎に長いキャピラリーが必要とな り, 集積化, 多検体化が困難となる。また, 非常に長い微 細キャピラリーを使用すると，圧力損失が大きくなるため, 集積化されたシステムの動作には出力の大きなポンプが必 要となる。また, 微細な流路を用いるため, チャンネル内 の流れは層流となり，ミキシングが困難になる。ミキシン グ効率が低下することにより，分析においては再現性に問 題が生じ，化学合成においては収率の低下などの問題が生 じる。そのため, 単位操作をチップ上に統合するためには

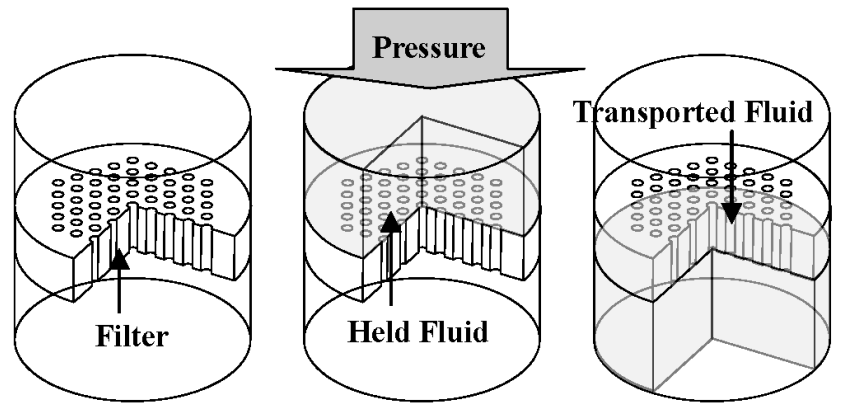

Fig. 1. Schematic illustration of the vertical fluid flow operation 


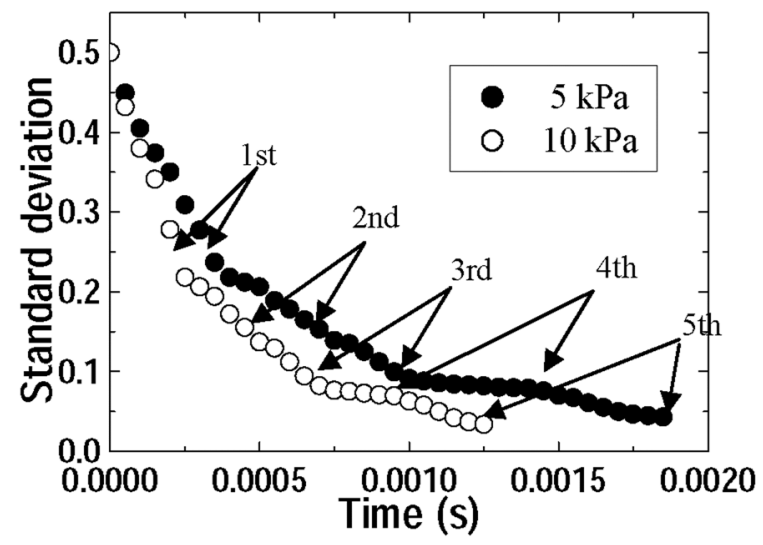

Fig. 2. Simulation result

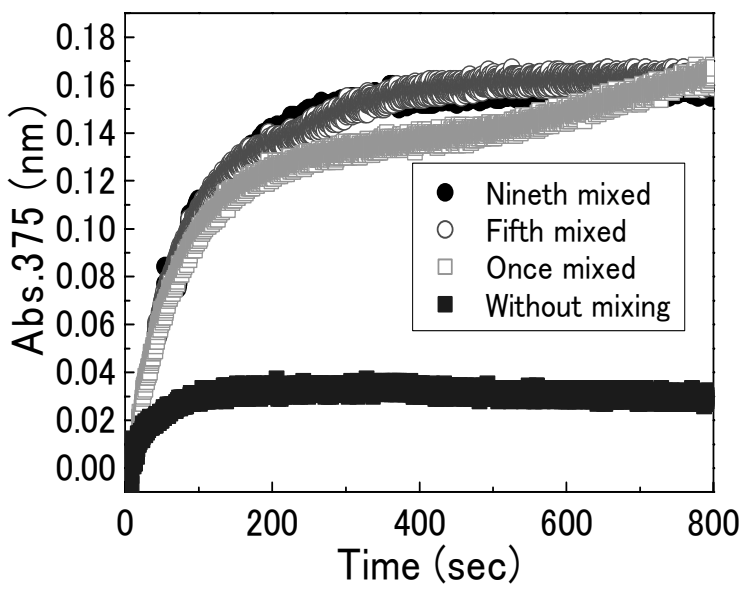

Fig. 3. Time shift of the enzyme reaction

マイクロミキサーをシステムに集積化する必要となる ${ }^{(1)(2)}$ 。 このような微細な空間内で，極微量のサンプルを検出し定 量するためには, 高い空間分解能と検出感度を有する検出 器が必要となる。このため高感度な検出手法が研究されて いるが(3)(4)，より実用的なるシステムとしては，安価で簡便 な手法で検出できることが好ましいと考えられる。

そこでわれわれは，平面構造であったマイクロ流体デバ イスを立体的な構造にした垂直型マイクロリアクターを提 案してきた ${ }^{(5)}(9)$ 。垂直型マイクロリアクターにおいての立 体的な構造内での流体操作は Fig.1 のように径数十 $\mu \mathrm{m}$ 程度 の微細なキャピラリーを 3 次元的に集積化したマイクロフ イルターを組み込み，これを用いて流体の挙動を制御する ことにより実現できる。キャピラリーの孔径は数十 $\mu \mathrm{m}$ と微 細であるため, 表面張力により溶液を保持することが可能 である。また，保持状態にある溶液を加圧することにより フィルターを透過させ垂直方向への流体輸送を実現するこ とが可能である（Fig.1）。このさい 3 次元的に集積化された キャピラリー内壁での流体の拡散，およびキャピラリー出 口での 3 次元的なコアンダ効果により, 溶液がフィルター を透過する際，において顕著なミキシングが生じる。

従来, 平面構造であったキャピラリーを三次元化するこ とにより, 立体的なキャピラリーの交差形状が許容され, キャピラリーのレイアウトの自由度が大きくなり, 集積化,
多検体化に有利となる。また, 先に述べたように溶液の保 持, 透過, 攪拌という複数の流体挙動制御機能を受動的か つ単純な構造に集約化することにより，作製プロセスが簡 便で信頼性の高いシステムとすることができる。

再現性のよい，単位操作のためには均一にミキシングさ れた混合溶液を得ることが必要となり，特に分析において は，不均一な溶液を用いることによりデータの再現性も悪 化する。逆に, 均一な溶液を用いりことにより, 反応を効 率よく行なうことが可能となり, 再現性が向上することが 期待でき, 検出感度そのものの上昇にもつながると考えら れる。本研究では, 三次元的なキャピラリークロスリンク 構造を形成した, 立体化学システムに実装可能な高効率マ イクロミキサーを提案する。

\section{2. 交差型マイクロフィルター}

〈2·1〉 マイクロフィルター われわれは，これまで にマイクロフィルター透過時におけるミキシング挙動を数 值流体力学（CFD）により推定してきた。初期条件として, フィルター上部に保持された溶液の塊に仮想的に化学種が 質量分率 1 で存在する領域を与える。次に溶液塊の上部を 加圧することによりフィルター構造を透過させ, 高濃度領 域の変形と, 化学種濃度の標準偏差によりミキシングの効 率を評価した。さらに，透過した溶液を逆方向に透過させ， 上下方向に繰り返し送液して, Fig.2 に示すような濃度標準 偏差の時間的推移をえた。これより判ることは，一度目の ミキシングにより顕著な攪拌が生じ, その後, 繰り返しに よってもさらに溶液を攪拌することができるということで ある。これと同様の操作を, 酵素反応を用いて行なった。 $\mathrm{C} 23 \mathrm{O}$ (酵素) を用いて, カテコール（基質）を開環反応さ せ, カテコール 2,3 ジオキシゲナーゼを得る。この反応で得 る生成物は $375 \mathrm{~nm}$ に吸収のピークを持っており，この波長 を分光光度計（USB2000：Ocean Optcs 社製）によりモニタ リングした。実験結果を Fig.3 に示す ${ }^{(8)}$ 。ミキシングを行な わず酵素と基質の層が分離した状態で放置した場合には, 生成物はほとんど検出されず, 逆に一度のミキシングを行 なった場合はこれに対して顕著な生成物の信号を検出し た。また, 繰り返し送液操作により 5 度, および, 9 度のミ キシングを行なうと, ほぼ同様の反応経緯をたどることか ら, 5 度以内のミキシングで今回の系に対しては十分な攪拌 が得られていることが示唆されている。しかしながら, よ り簡単な単位操作のためには, 一度の攪拌により十分な攪 拌効果を得ることが重要であり, より高効率な攪挥効果を 示すミキサーの開発が必要となる。

〈2·2〉＼cjkstart交差型マイクロフィルターママイクロフィル ターは Fig. 1 に示すような, まっすぐなキャピラリーのアレ イ構造であった。この中での流体の攪找効果はキャピラリ 一内での放物線状の流速分布に起因寸る流体の拡散, およ びキャピラリー出口でのコアンダ効果によるものであっ た。さらに, キャピラリーを交差させ, 3 次元的な流体の振 る舞いを積極的に用いることでミキシングの高効率化が実 
現できる。これは，キャピラリーを交差させることにより， 流れが衝突し，更なる攪拌の効果を付加することができる。 特に, X 線リソグラフィーを用いることにより Fig.4 に示す ような, 一般的な微細加工技術では，複雑な作製プロセス を要する任意の交差形状を作製可能であることや，キャピ ラリーの断面形状も任意に設計できるなどの利点がある。

〈2·3〉交差型マイクロフィルターの流体挙動解析 先に述べたように，キャピラリーを交差させることにより 新たな 3 次元的な流体の挙動を誘起させて高効率なミキシ ングを実現する。特に Fig.4 に示すように，交差部での流体 の挙動はキャピラリーの中心が完全に重なった形状と, 中 心がずれた状態で交差した場合とでは，流体の挙動が異な った様相を示す。たがいに交差するキャピラリーの中心を ずらすことにより，キャピラリー内の層流により互いに反 発し交差するキャピラリーに流れ込む流れと，反発せずに

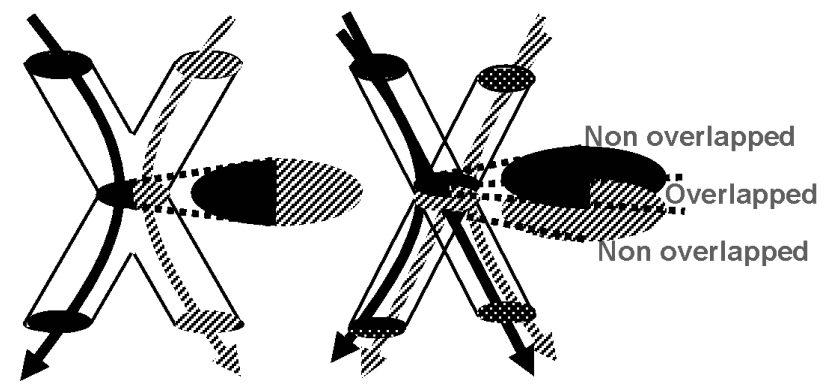

Fig. 4. Fluid behavior cross type filter

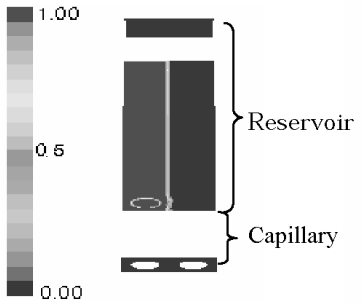

(a) Initial condition

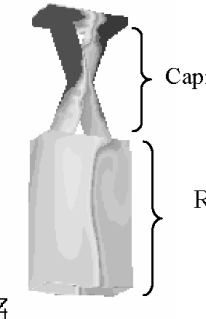

(b) ${ }^{4}$ Full cross-linked (After transmission)

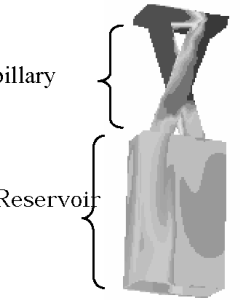

(c) Half cross-linked (After transmission)
Fig. 5. Analysis model of cross type filter

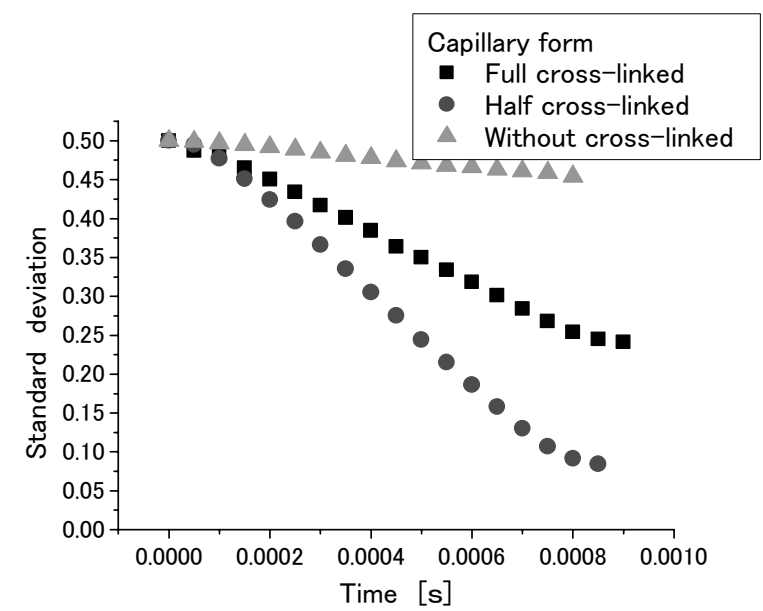

Fig. 6. Simulation result of cross type filter
直進する流れとの二種類の挙動を示し，顕著な攪拌効果を 得ることができる。一方, 中心が完全に重なった場合では, キャピラリー内の流れは層流であるため流れは互いに反発 しあい，攪拌効果が減退することが推測できる。このよう な，推測を検証するために，我々は CFDにより流体挙動の シミュレーションおよび攪挥能の推定を行なった。シミュ レーションに用いる解析モデルは立体的な交差形状である ため 3 次元モデルを作成し, Fig.5(a)に示すような化学種が 左右に分割されて分布する初期条件より，加圧により流体 塊が交差したキャピラリーを一度透過する様子を解析し た。また, キャピラリーの交差形状は直径 $40 \mu \mathrm{m}$ のキャピラ リーの中央が完全に重なるものと, $20 \mu \mathrm{m}$ ずれた状態で交差 するもの，および比較対照として交差しない形状について 解析を行なった。なお, 解析には CFD ソフトウェアである FLUENT を用いた。Fig.5 に CFD により得た流体の挙動およ び, Fig.6 解析により得た流体透過中における濃度標準偏差 の時間的推移を示す。Fig.5 に示すように, キャピラリーの 中心を一致させた場合, 左右の入り口から浸入した流れが 交差部で衝突している様子が示されている。これに対して, キャピラリーの中心をずらした場合では，反発しあう流れ と直進する流れとの 2 種類の挙動により交差部を通り過ぎ ることにより二つの流れの混合が生じる。Fig.6 の標準偏差 が示すように，交差部での中心のずれが，ミキシングに顕 著な影響を与えることを示しており，本手法の優位性が明 らかになる結果となった。

\section{3. 作製および評価}

〈3·1〉交差型マイクロフィルター作製プロセス 交 差型マイクロフィルターは放射光を用いた X 線リソグラフ イーを用いて作製した。X 線リソグラフィーでは X 線の吸 収体 $(\mathrm{Au})$ によりパターニングされた X 線マスクを介し, レジストに X 線を照射する。X 線を照射することにより，X 線マスクのパターンがレジストに転写され, 現像液に浸漬 することにより構造体が形成される。以上の工程は光源こ そちがうものの一般的に用いられているフォトリソグラフ イープロセスと酷似したプロセスであるが，短波長（高エ ネルギー）の X 線を用いることにより， $\mathrm{mm}$ オーダーとい う，レジストの深部にまでおよび超高アスペクト比の加工 が実現できる。このような加工プロセスを用いることによ り，一般的な作製プロセスでは実現困難である, 流路の軸 方向に掘り進む加工を実現できる。交差型マイクロフィル ターの作製には Fig.7 に示すように, 多段階にわけて X 線を 照射する。今回用いた X 線露光装置は 5 軸露光ステージが 備え付けられており，ステージの傾きを制御し，2 回の $\mathrm{X}$ 線照射を行なうことで交差形状のパターニングを行なうこ とができる（Fig.7）。高アスペクト比の微細加工が可能なプ ロセスには SU-8 などの高感度な厚膜レジストを用いた UV-LIGA プロセスが挙げられるが，ネガ型のフォトレジス トでは照射された部分が硬化するため，このような形状を 作製することは不可能である。交差型フィルターのような 
三次元の構造体はUV では作製が困難である。

作製した交差型マイクロフィルターの走查型電子顕微鏡 （SEM）写真を Fig.8 に示す。作製したキャピラリーの直径 は $40 \mu \mathrm{m}$ であり, フィルターの厚みは $400 \mu \mathrm{m}$ である。 X 線 照射時の傾きはキャピラリーが 2 回交差するように設定し た。キャピラリーの交差を半分ずらした状態での作製に成 功していることが判る。

〈3·2〉 交差型マイクロフィルターの評価＼cjkstart作製した 交差型フィルターの攪拌能を評価するために，カテコール (catechol）の開環反応を用いてその効果の検証を行った。混 合物が均一に混ざり酵素が基質溶液に均一に分布する状態 では効率よく反応がす寸むため, 酵素反応の反応速度を評
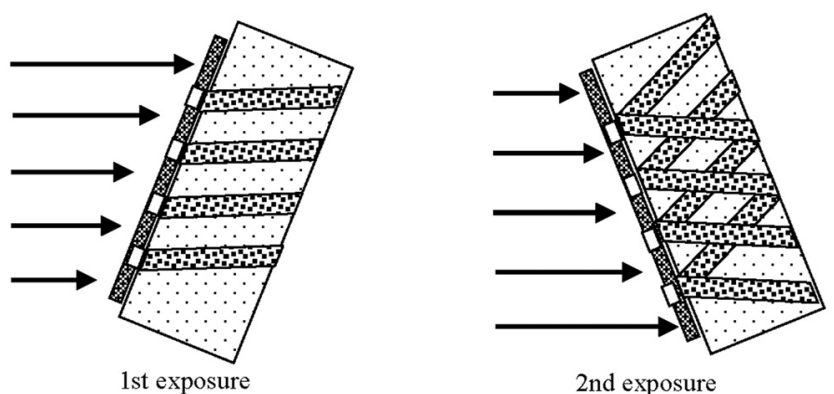

Fig. 7. Schematic illustration of multi step exposure

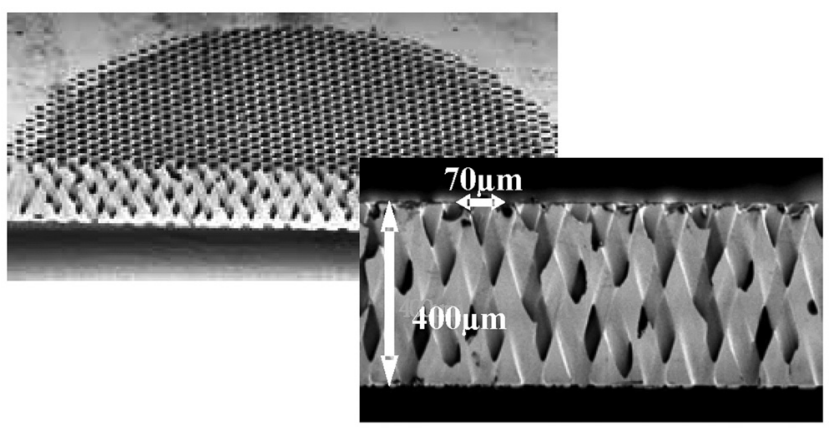

Fig. 8. SEM image of cross-linked fluid filter

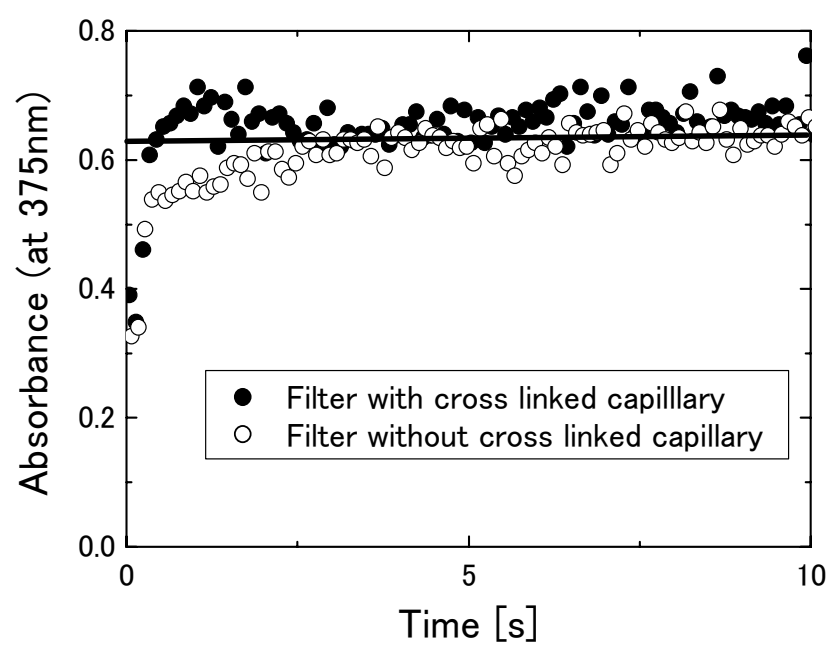

Fig. 9. Time shift of the enzyme reaction
価することによりミキシングを評価した。すなわち，吸光 度の時間変化を計測し, 酵素反応がより早く収束するほど 均一な溶液が得られていると仮定した。生成物は $375 \mathrm{~nm}$ に 吸収を持つため, 光ファイバー分光光度計 (Ocean Optics 社 製）により反応の測定を行った。カテコールを $\mathrm{pH} 7.0$ に調 整した $10 \mathrm{mM}$ のリン酸バッファ $(\mathrm{PB})$ に溶かし $0.1 \mathrm{mM}$ とし, これを基質とした。酵素は，20 倍希釈したカテコール $2 \cdot 3$ デオキシナーゼ（C23O）を使用した。評価に用いたフィル ターはキャピラリーの交差形状を有さないフィルターと交 差型フィルターを用い行なった。測定結果を Fig.9に示す。 Fig.9 に示すラインは酵素の活性を示し，これは酵素反応が 終結した際の吸光度である。結果より交差型マイクロフィ ルターを用いた場合，ストレートフィルターを用いた場合 より反応が終結するまでの時間が短縮されていることが見 出せる。これは，より高い性能を有するミキサーを使用し て溶液を攪拌したため, 酵素が基質溶液中に均一に分布す ることになり，効率よく反応が進行したためと考えられる。

\section{4. まとめ}

本稿では, 垂直型マイクロリアクター内での, 高信頼性・ 高効率な単位操作のための, 交差型マイクロフィルターを 提案した。CFD により示された流体挙動によると, ずれた 交差形状を用いることにより, キャピラリー内での流れを 複雑に分割する挙動を利用でき, 高効率に攪拌が進行する ことが判明する一方, 完全に中心を一致させた交差形状を 用いる場合には，キャピラリー内での層流の特性によりミ キシングの効率が比較的悪いことが示された。このような 交差形状を簡便に作製できる唯一の手法は放射光を用いた ディープ X 線リソグラフィーであり, 我々はこれにより交 差形状を任意に制御したマイクロミキサーの作製に成功し た。ミキサーの性能を従来の構造と比較するために酵素反 応を適用した結果, 酵素反応の高速化が確認できた。これ は，ミキサーが高効率化され，従来の交差形状を有さない 構造により攪拌した場合よりも溶液を均一に攪拌する効果 が得られたためと推測される。

高効率, かつ信頼性の高いマイクロミキサーは分析, 合 成等様々な応用面で非常に重要な流体素子であり，特に分 析では均一に溶液を混ぜることによりデータの再現性や, 検出感度そのものの上昇が期待できる。

(平成 20 年 5 月 23 日受付)

\section{文献}

(1) R. Yang et. al.: "A rapid micro-mixer/reactor based on arrays of spatially impinging micro-jets”, J. Micromech. Microeng., Vol.14, p.1345 (2004)

(2) H. M. Xia et. al.: "Chaotic micromixers using two-layer crossing channels to exhibit fast mixing at low Reynolds numbers", Lab. Chip, Vol.5, p.748 (2005)

(3) E. Tamaki et. al.: "Single-Cell Analysis by a Scanning Thermal Lens Microscope with a Microchip : Direct Monitoring of Cytochrome c Distribution during Apoptosis Process", Anal. Chem., Vol.74, p.1560 (2002) 
(4) R-H Horng et. al.: "PMMA-based capillary electrophoresis electrochemical detection microchip fabrication", J. Micromech. Microeng., Vol.015, p.6 (2005)

( 5 ) Y. Utsumi, T. Asano, Y. Ukita, K. Matsui, M. Takeo, and S. Negoro : "Proposal of a new microreactor for vertical chemical operation", J. Vac. Sci. Technol. B, Vol.24, pp.2606-2611 (2006)

(6) Y. Ukita, T. Asano, K. Fujiwara, T. Yokoyama, K. Matsui, M. Takeo, S. Negoro, T. Saiki, and Y. Utsumi : "Novel characteristics of multifunctional fluid filters fabricated by high-energy synchrtron radiation lithography", Jpn. J. Appl. Phys., Vol.45, pp.7203-7208 (2006)

（7）内海裕一・浮田芳昭：「放射光 LIGA プロセスを用いた 3 次元マイ クロ化学システムの開発」, ケミカルエンジニヤリング, $15,11, \mathrm{p} .32$ (2007)

（8）藤原邦代 他:「多機能フィルターを用いた垂直流体操作の挙動予測 と検証」, 電学論 C, 127, 2, pp.201-216 (2007-2)

(9) Y.Ukita et. al.: "Application of vertical microreactor stack with polystylene microbeads to immunoassay", Sensors and Actuators A. (2008) in press

(10) E.W. Becker, W. Eherfeld, P. Hagmann, A. Maner, and D. Münchmeyer : "Fabrication of microstructures with high aspect ratios and great structural hights by synchrtron radiation lithography, galvanoforming, and plastic moulding (LIGA process)", Microelectronic Engineering, Vol.4, pp.35-56 (1986)

(11) Y. Utsumi and T. Kishimoto : "Large area and wide dimension range x-ray lithography for lithographite, galvanoformung, and abformung process using energy valuable synchrtron radiation", J. Vac. Sci. Technol. B, Vol.23, pp.2903-2909 (2005)

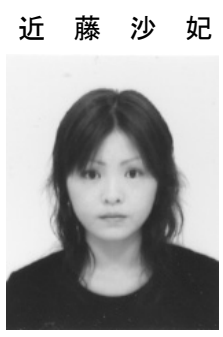

（非会員） 2008 年 3 月兵庫県立大学卒業 現在, 兵庫県立大学大学院工学研究科機械系工学専攻 博士前期過程在学中。

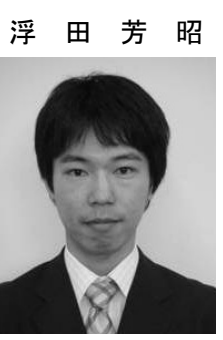

(学生員) 2006 年 3 月兵庫県立大学大学院工学 研究科機械系工学専攻博士前期過程修了。現 在, 兵庫県立大学大学院工学研究科博士後期課 程在学中。日本学術振興会特別研究員 (DC2)。

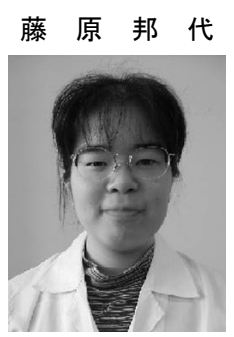

（非会員） 2008 年 3 月兵庫県立大学大学院工学 研究科機械系工学専攻博士前期過程修了。現 在, 総合研究大学院大学物理化学研究科構造分 子科学専攻博士後期課程在籍中。

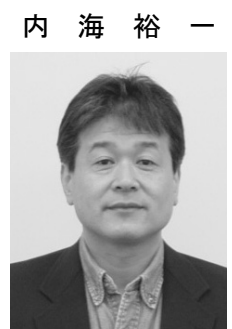

(正員) 1984 年名古屋大学大学院工学研究科 修士課程修了。同年, 日本電信電話公社入社。 物性科学基礎研究所主任研究員を経て, 2000 年 3 月より兵庫県立大学・高度産業科学技術研 究所 助教授。現在は流体デバイスを主とする ナノ・マイクロシステム研究に従事。博士（工 学)。日米機械学会共催・材料プロセス国際会 議 2002（M\&P2002）ベストポスター賞, 2003 年精密工学会ベストオーガナイザー賞等を受賞。 